\title{
Lymph Node Cortex
}

National Cancer Institute

\section{Source}

National Cancer Institute. Lymph Node Cortex. NCI Thesaurus. Code C33029.

The portion of the lymph node that contains nodules with germinal centers where $B$ lymphocyte mature into plasma cells after activation. The nodules are separated by diffuse lymphatic tissue, lymph sinuses and trabeculae. 